\title{
International finance and economic institutions: Can Russian Ruble become the world's leading currency?
}

\author{
Luboš Smutka \\ Czech University of Life Science Prague, Prague, Czech Republic, e-mail: smutka@pef.czu.cz \\ Patrik Rovny \\ Slovak University of Agriculture in Nitra, Nitra, Slovakia, e-mail: patrik.rovny@uniag.sk \\ Kamil Maitah \\ Czech University of Life Science Prague, Prague, Czech Republic, e-mail: maitahk@pef.czu.cz \\ Pavel Kotyza \\ Czech University of Life Science Prague, Prague, Czech Republic, e-mail: kotyza@pef.czu.cz
}

Citation: Smutka L., Rovny P., Maitah K., Kotyza P. (2021). International finance and economic institutions: Can Russian Ruble become the world's leading currency? Terra Economicus 19(3): 93-104. DOI: 10.18522/2073-6606-2021-19-3-93-104

Our paper focuses on the recent leading institutional trends in finance and economy of the Russian Federation. In particular, we analyze the past developments and economic crises that impacted the Russian economy and caused many adverse effects to its development. We focus on the role of economic sanctions imposed by the Western countries on the Russian economy and the outcomes of these sanctions. Then we discuss the country's current economic and intellectual potential that constitute its valuable assets and the ways they can be monetized. We contemplate over the dependence of Russian economy on world's oil prices and discuss whether novel information and communication technologies might take the role of oil in Russian economy. The article discusses the issue of whether Russian Ruble might become the world's leading currency. Our findings show that under certain conditions Russian Ruble might be used as another world's reserve currency, especially in the face of recent economic and political issues, such as Brexit or American and Chinese trade wars. We demonstrate that Russian Ruble has the potential to follow the path set by the Digital Currency Electronic Payment (DCEP), a digital currency issued by the central banks, such as, for example, the recently launched "digital yuan" (also known as the e-CNY or digital RMB) issued by the People's Bank of China. Such a currency provides enormous opportunities for the digitalization of financial markets and changing the institutional aspects of their functioning.

Keywords: international economics; institutional change; banking and finance; Ruble; Russian Federation

Acknowledgements: The paper is a part of the internal research project 2021B0002, solved at the Department of Economics, Faculty of Economics and Management, Czech University of Life Sciences in Prague.

JEL codes: F30, 043, 016

(ㄱ Л. Смутка, П. Ровны, К. Майтах, П. Котыза, 2021 


\title{
Международные финансово-экономические институть: сможет ли российский рубль стать ведущей мировой валютой?
}

\author{
Любош Смутка \\ Чешский сельскохозяйственный университет в Праге, Прага, Чешская Республика \\ e-mail: smutka@pef.czu.cz \\ Патрик Ровны \\ Словацкий сельскохозяйственный университет в Нитре, Нитра, Словакия \\ e-mail: patrik.rovny@uniag.sk \\ Камил Майтах \\ Чешский сельскохозяйственный университет в Праге, Прага, Чешская Республика \\ e-mail: maitahk@pef.czu.cz

\section{Павел Котыза} \\ Чешский сельскохозяйственный университет в Праге, Прага, Чешская Республика \\ e-mail: kotyza@pef.czu.cz
}

Цитирование: Smutka L., Rovny P., Maitah K., Kotyza P. (2021). International finance and economic institutions: Can Russian Ruble become the world's leading currency? Terra Economicus 19(3): 93-104. DOI: 10.18522/2073-6606-2021-19-3-93-104

Наша статья описывает последние наиболее важные институциональные тенденции в финансах и экономике Российской Федерации. В частности, мы анализируем прошлые события и экономические кризисы, которые повлияли на российскую экономику. Кроме того, мы анализируем роль экономических санкций, наложенных западными странами на российскую экономику, и результаты этих санкций для обеих сторон. Затем мы обсуждаем текущий экономический и интеллектуальный потенциал страны, составляющий ее активы, а также способы их монетизации и использования. Кроме того, мы анализируем вопрос зависимости российской экономики от мировых цен на нефть и то, могут ли новые информационные и коммуникационные технологии сыграть роль нефти в российской экономике. Представляет интерес роль новейших решений в области искусственного интеллекта для экономического развития и то, сможет ли Россия использовать их в своихинтересах. Отдельное внимание уделено условиям, при которых рубль может занять прочное место на мировых финансовых рынках наряду с долларом США, британским фунтом, евро и китайский юанем. Наши результаты показывают, что при определенных условиях российский рубль может использоваться в качестве резервной валюты другого мира, особенно ввиду недавних экономических и политических проблем, таких как Breхіt или торговые войны между США и Китаем. Мы демонстрируем, что у российского рубля есть потенциал стать электронной валютой, аналогичной выпущенной центральными банками, например, недавно запущенному «цифровому юаню» (CNY), выпущенному Народным банком Китая. Такие перспективы означают огромные возможности для цифровизации финансовых рынков и изменения институциональных аспектов их работы.

Ключевые слова: международная экономика; институциональные изменения; банковское дело и финансы; рубль; Российская Федерация

Благодарность: Данная статья является частью внутреннего исследовательского проекта 2021В0002, решаемого на кафедре экономики факультета экономики и менеджмента Чешского сельскохозяйственного университета в Праге. 


\section{Introduction}

International finances and economics in Russia underwent many changes since Perestroika and the fall of Communism. Economic troubles of the 1990s, the fall of Ruble, a national currency, and liberal reforms aimed at regaining strength for the Soviet and then Russian economy, left many opened issues and undermined the trust in banks and financial institutions of many Russians (Knight, 2003; Shleifer, Treisman, 2005; Robinson, 2013; Kudrin, Gurvich, 2015; Morozko, Didenko, 2018; Krivko et al., 2019; Sachs, 2019). It took Russian economy more than 20 years to build the new strong institutions and to regain this trust (Rutland, 2013; Fifka, Pobizhan, 2014; Berezin et al., 2018).

Nowadays, Russian banks and financial institution operate under strict standard. This is done in order to set up and promptly follow the rules for the execution of the statements describing the financials assets and liabilities which are necessary and crucial for obtaining the up-to-date information and data on the financial markets and the stock prices. This, in turn, is crucial for the prediction of the future cash flows (Veselovsky et al., 2018). The binding rules describe the requirements for the estimation of the credit losses and the value of various financial instruments. Such important measures and the fair value hedge of the financial portfolio, interest rate and the rate of the inflation can also be derived from the financial data. Requirements for net stability financing and leverage (for systemically important credit institutions) applicable from 2018. All of the above is calibrated based on the current economic situation in the country and banks operating in a given country with a valid licence which allows to aggregate the results and to get a clear overview of the valuation of assets and the prognosis for development of the situation in the nearest future. Therefore, the Bank of Russia reserves the right to set the specific conditions for the economic assessment of banks (Bulatova, Ipatova, 2021). The main reason for this muted enthusiasm is that although the Bank of Russia offers informal preliminary evidence that it would be inclined to approve credit derivatives in order to relieve credit risk on the grounds of capital adequacy, it has so far taken no concrete steps to achieve this goal.

With regard to the above, it has to be mentioned that Russian economic reforms that started in the early 1990s were inspired by the model of securities regulation that originated in the United States and which, at that time, was considered to be the most efficient and liquid way the capital markets could (and most likely) should function (McCarthy, Puffer, 2002). The Russian financial regulation has since decoupled from the actual U.S. model and largely follows international trends. Significant steps have been taken in recent years to expand the range of financial instruments and improve discipline in the financial markets. In the period of the regulatory duopoly that ended on September $1^{\text {st }}$ 2013, the most important regulator of capital market activity was the firms. For its part, the Bank of Russia has established the procedure for issuing securities by credit institutions and has registered their prospectuses. Through its participation in key market infrastructure projects (such as the Moscow Stock Exchange, formerly known as MICEX) and its leverage as a bank supervisory authority, the Bank of Russia indirectly exerted a significant influence on the functioning of the market.

One has to observe that the banks of Russia and Belarus are more active lenders than those of Kyrgyzstan and Kazakhstan, although the European Union banking systems of the real economy do not provide substantial funding. Securities (equity) sector is poorly diversified in the Eurasian Economic Union (EAEU) financial markets and plays a different role in the respective economies. The stock market in Kazakhstan is relatively more developed than the other EAEU markets.

The Russian banking sector brought a certain amount of innovation to the forefront starting from 2018. One of the key changes become the enhanced security of the cash transfers and remittances that included many security measures and safety tools. Previously, such information was considered banking secrecy which often posed many problems for the bankers who wished to verify or to check the validity of transfers or the origin of assets, as far as the end user suffered from banking services (Gershman et al., 2018).

This paper is structured as follows: Section 2 describes the situation with the energy markets in Russia and highlights the dependency of the Russian economy on fossil fuels. Section 3 analyses the occurrence and the impacts as well as the role of the economic crises in Russia. Section 4 tackles the 
place and the relevance of the currency policies in Russia. Section 5 describes the problem of the economic sanctions imposed by the Western countries against Russia. Section 6 contemplates on the research question whether the Russian Ruble can become the world's leading currency and proposes some interesting solutions. Finally, the Conclusions and implications section closes this paper and offers some insights and perspectives stemming from this study.

\section{Russian economy and energy markets: A dependency of fossil fuels}

Most of the other goods were so competitive (or possibly produced in insufficient quantities) that it would either require a substantial drop in the dollar's price or an incredible increase in exports to offset lost revenue from oil exports. In a way, many countries become victims of the so-called "Dutch disease" when the soaring exports of fossil fuels generates hard cash making the policy-makers to focus on expanding the energy-exporting industry further and creating the shortages of grains and other products that often need to be exported from abroad. This is exactly what happened to the Soviet Union in the 1970s and 1980s and set the dependency path for Russia as a successor of the USSR. Of course, Russia is heavily dependent on oil and gas. Fuel exports make up around $66 \%$ of total goods exports, compared with around $61 \%$ in 2007 . It sterilized the oil revenues to counteract the upward pressure on the Ruble, and it kept excess funds in case when the revenues were dropping (Bradshaw et al., 2019).

Moreover, even in the boom years, the country has generally resisted the political temptation to borrow against future hydrocarbon revenues for investment. Since oil and gas would be less lucrative, the investment money should flow elsewhere. The good news for Russia is that a slow decline in oil and gas prices is more likely than collapse. In addition, government policy may slow the decline in the Ruble, even if hydrocarbon prices fall rapidly. The Russian government understand the importance of the renewable energy, the smart cities and the information technologies that should replace the old and obsolete solutions in the Russian energy sector (Strielkowski et al., 2021).

There are several factors that affect the price of oil: supply, market anxiety, policy implications for trade, use of technology in production and natural disasters. Future contracts of oil trade between countries at a certain price may also affect the market. Investments in pipelines to transport oil reduce transport costs along with the price of oil. However, one of the most important determinants of the price of oil is OPEC. It turned out that the Soviet economy was unable to respond adequately to the sharp rise in the marginal cost of oil production (which tripled in the 1970s and 1980s) and the rise in world oil prices. The first factor should provide incentives to increase the efficiency of oil extraction and transport, which can be expected from a market economy. The developed gas fields were so large that the marginal cost of their exploration was minimal. On the one hand, it would be possible to significantly increase performance at the same cost, thereby increasing the available oil rent. In the West, a significant proportion of private car and homeowners responded much faster to changing energy costs (though industrial consumers responded much more quickly). As crude oil is rapidly becoming more expensive despite equal real incomes, it might be less profitable to use it and might be better to substitute it with the other sources of energy (e.g. renewable energy sources as one of the current options). Since real income in countries that are heavily dependent on oil imports decreases when oil is expensive, and the demand for oil income has a positive elasticity (quite high, but below 1.80), oil demand also decreases due to the income effect. The decline in the prices of oil all around the world we are witnessing today might mean the change of the state of the game and depriving the oil exporters of their gains. However, this has been obvious for many years as far as many Russian stakeholders and policy-makers understood the situation and called for the modernization of the Russian energy systems, the creation of the new vision of economic development and the change of priorities for the Russian economy.

In spite of all that, Russia has set on the path of modernizing its energy sector and reaching the low-carbon or even decarbonized economy as dictated by the world's leading trends (Rausser at al., 2018; Ljovkina et al., 2021). The institutional settings of the energy market design are changing slowly but gradually (Strielkowski et al., 2019). The country is also preparing for deploying sustain- 
able energy projects even though the risks and the costs associated with them might be quite high (Chebotareva et al., 2020).

\section{The role of economic and financial crises}

Despite the high oil price and renewed access to credit markets, Russia's GDP growth averaged a measure of around 2.4 percent between 2011 and 2014. The main reasons for the downfall were obvious - shrinking oil prices, lack of foreign debt and falling reserves. Russian Federation faced the opposite problem in the context of weak economic growth and an oil price only half as high as in 2014. Overall, the changes in the budgetary process have paved the way for more accommodative fiscal policies to mitigate low oil prices and weaker economic growth (Voskoboynikov, 2017).

Some analysts believe that Russia can afford a modest budget deficit with considerable reserves and low public debt, without jeopardizing the sustainability of public finances. Russia has two fiscal buffers, the Reserve Fund and the National Welfare Fund (NWF), both of which were under pressure due to worsening economic conditions. U.S. and EU sanctions make it impossible for Russia to borrow on international markets. Russia can therefore rely only on accumulated budgetary reserves and domestic loans to finance budget deficits. Domestic borrowing will remain limited due to insufficient depth of the domestic financial market, limited confidence in the Ruble and vulnerability of part of the banking sector. In addition, general government expenditure will increase by more than one percentage point of GDP, mainly due to a declining denominator (real GDP).

The Russian government is happy to continue its oil craze and investment in other parts of the economy has remained weak. Low technological innovation, an aging workforce and widespread corruption make it difficult to obtain support from companies abroad. Lower oil prices and economic sanctions hit the economy at about the same time, making it difficult to quantify the impact of sanctions alone. Prolonged monetary easing, lower inflation and supportive fiscal policies are likely to boost investment activity.

On the one hand, a slowdown in inflation, an improvement in consumer confidence, a stable Ruble, and easing of the central bank's monetary policy had a positive impact on domestic demand in the third quarter. On the other hand, retail sales growth in the third quarter collapsed as a result of higher unemployment, suggesting that consumer demand remained weak over the quarter. From the late 1990s onwards, foreign banks took control of domestic banking systems in most countries, making them the most important lenders to households and businesses. CEE countries were regularly hit by currency crises, followed by periods of temporary economic recovery with speculative real estate, consumer and capital markets booms. The overseas takeover completed the process of financialization of the CEE banking sector, a shift of lending activities for production to speculative financial practices. Careful risk management of the acceptance of collateral at recipient banks was recommended to avoid possible negative effects. To champion this policy, the IMF central bank highlighted potential systemic liquidity risks in the banking sector, which increased demand for CBR funding. The provision of liquidity was therefore presented as a means of strengthening the monetary policy transmission mechanism and improving the functioning of the interbank market.

The first cost group must be paid as soon as an adjustment process is completed. A country with a current account deficit will eventually endure permanent economic losses, accompanied by a new settlement of payments. Transition costs form the second group of adjustment costs and reflect the costs of the change itself. The scale of the crisis is testimony to a sacrifice imposed on a country in deficit in terms of its reduced share of combined world production and revenues. Under President Yeltsin, the idea of a grey economy was rather meaningless, with much of the economy based on bartering and tax payments unimportant, fuelling the ongoing crisis. Since 2000, the tax authorities have been streamlined, and over the last two years, Russia has experienced a tax revolution with vastly improved efficiency. The state has tried to end the practice of wages in envelopes and to induce workers in the informal sector to pay taxes and social security contributions without much success. As a result of incomplete economic reforms in the 1990s and their partial reversal, Russia is not a friendly country for domestic and foreign companies. In the Transparency International Cor- 
ruption Perception Index of 2021, Russia ranks $136^{\text {th }}$ out of 174 countries ${ }^{1}$. According to the Heritage Foundation Index of Economic Freedom, Russia is in 92 out of 178 countries ${ }^{2}$. These relatively poor values have either remained unchanged for several years or have even deteriorated.

The economic crisis in Russia in 2008 has definitely contributed to consolidation in several sectors. In addition to macroeconomic effects (such as inflation, volatile exchange rates and limited budgets), economic crises can worsen competitive conditions for companies and worsen the perspectives on the labor markets as it happened in other countries many times before in the past (Glazar, Strielkowski, 2010; Liefert et al., 2019). Crises often increase market concentration by uncovering and ultimately killing companies with variable access to capital, weaker political relationships and lower margins. More importantly, however, economic crises are the main reason for the weakening of competition in Russia: stronger government interventions and stronger regulation of markets. The Russian economy also reduces opportunities for other political forces to defend their interests. Today's Russian government has sought to achieve consensus among key economic elites by limiting the number of actors allowed participate in decision-making. By preventing real competition between companies in key sectors of the economy, the government has simplified governance issues.

\section{Currency policy in Russia}

In order to become a business entity operating with foreign currency in Russia, one needs to obtain a special license. Obtaining such a license takes one to several months and requires the submission of a number of documents (Chernopyatov et al., 2018). Goods (works, services) may not be sold in the Russian Federation for cash in foreign currency. Foreign private individuals can exchange cash for Rubles in special bureaux de change. The savings for a period consist of investments in foreign exchange and Ruble deposits less changes in foreign currency and Rubles loan indebtedness, changes in cash (Ruble and foreign currency), net asset purchase, real estate acquisition, life premiums and interest pension insurance.

Russian Ruble underwent a series of crises and falls which can be show at the history of its exchange rate for U.S. dollar and euro (see Fig. 1 that follows).

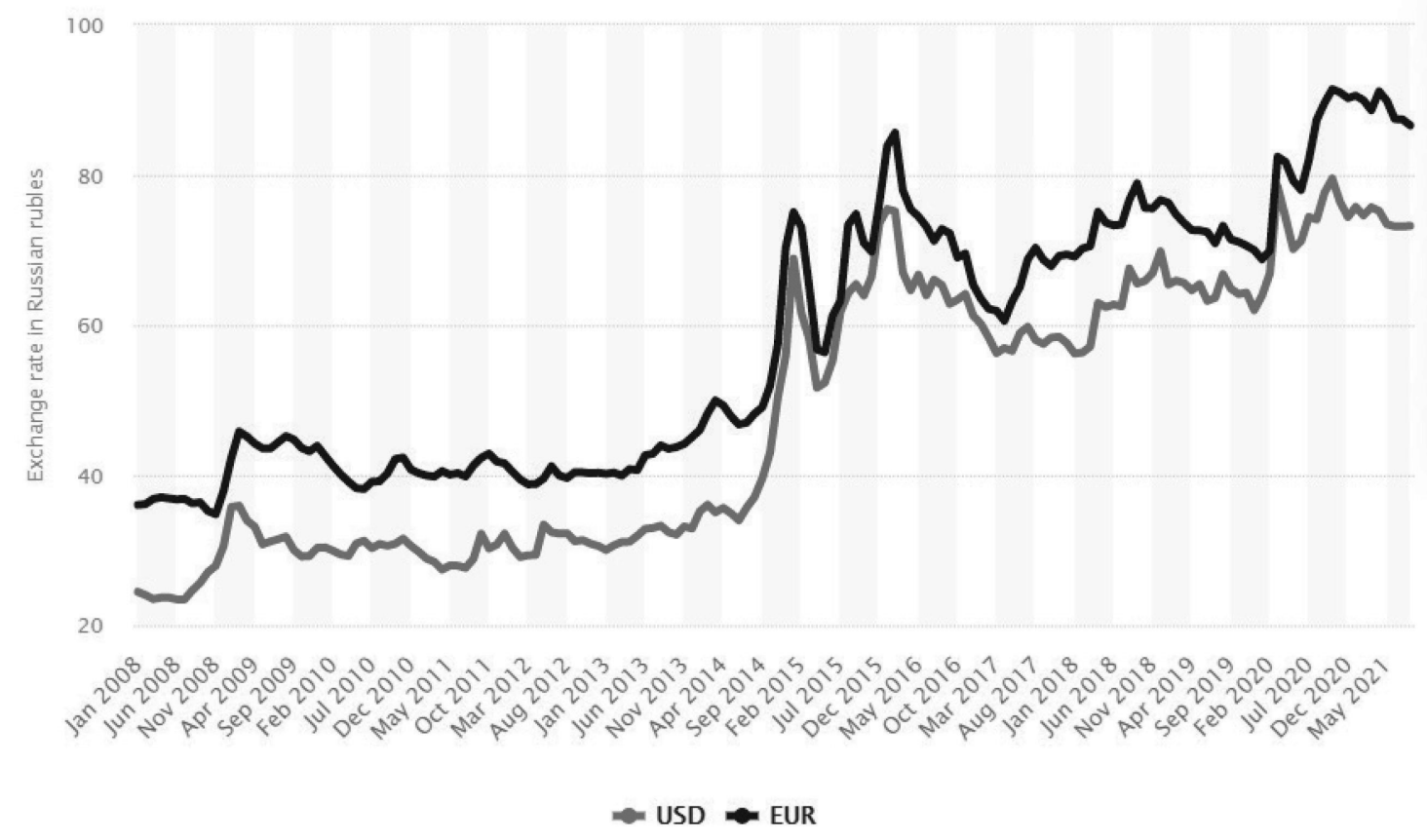

Fig. 1. Average USD and euro EUR exchange rate to RUB (2008-2021)

Source: Statista (2021). Average monthly U.S. dollar (USD) and euro (EUR) exchange rate to Russian Ruble (RUB) from January 2008 to August 2021 (https://www.statista.com/statistics/1200821/usd-eurrub-exchange-rate-monthly)

\footnotetext{
1 Transparency International (2021). Corruption Perception Index (https://www.transparency.org/en/cpi/2014/index/dnk).

2 Heritage Foundation (2021). 2021 Index of Economic Freedom (https://www.heritage.org/index).
} 
It became a bad tradition in Russia that in times of economic and financial instability, the population tends to build up cash reserves and foreign currency deposits, delete Ruble deposits, absorb fewer new loans, and repay those formerly taken (Johnson, 1994; Mau, 2017). An increasing share of disposable income used to build up foreign currency savings and reduce Ruble revenue is linked to dramatic exchange rate fluctuations in unstable periods and is supported by expectations that the Ruble will continue to depreciate. The notorious success story of dramatic increases in inflation and Ruble depreciation inhibits the decline in inflation expectations and impedes real interest growth.

Russian Federal budget deficits were about 3-4\% of GDP in the 2010s, however thanks to the accumulated budgetary reserves which accounted for about $10 \%$ of GDP this was not a problem (Kudrin, Sokolov, 2017). With the Ministry of Economic Development of Russia attempting to foster the economic growth, the International Monetary Fund, the World Bank and the EBRD are forecasting a high probability of a further decline in the future years which is reinforced by the economic recession and slowdown caused by the COVID-19 pandemic. In addition, the Russian Ministry of Finance is determined to eliminate the budget deficit which will increase the pressure for additional budget cuts and reduce the quality of public sector services (Nie et al., 2020). Requirements for net stability financing and leverage (for systemically important credit institutions) are not applicable. From 1 January 2018, applicable net stability financing and debt financing requirements (for systemically important credit institutions).

Russian banks in financial difficulties are prone to bank bills as they rely on customer deposits, which can be debited quickly or without notice. As bank failures can trigger a wide range of adverse events, including economic recessions, policymakers maintain deposit-guarantee schemes to protect depositors and comfort them by not putting their funds at risk. In comparison to the U.S., deposit protection was provided to protect banks with small lots when there were regulations for branches.

\section{Economic sanctions in Russia: Winners and losers}

The question of the effectiveness of the economic sanctions imposed by the Western countries against Russia and their impact on the Ruble exchange rate has, from a scientific point of view, been little investigated, despite all its debatability (Klinova, Sidorova, 2019). In this regard, the purpose of this section is to investigate and confirm the hypothesis that the reason for the decline in the Russian national currency following the introduction of foreign trade restrictions was not sanctions but coincidentally coincided with a collapse in oil prices at the time of their introduction.

The results obtained support the fact that the Ruble exchange rate in the period from 2014 to 2017 and at other time intervals reacts primarily to the state of the economy and oil prices and does not reflect the size change in any practical way from external sanctions pressure. In continuation of the theme of the change in the Ruble exchange rate after the imposition of sanctions, it should be noted that the decline in oil prices has become the key, but by no means the only factor contributing to the economic destabilization in Russia in 2014. Some support for negative trends in the initial phase of the crisis was the desire of the Russian central bank to control inflation to keep it at 5 percent. The Russian Central Bank believed that this decision would reduce the activity of speculators who had launched a global game against exchange rate differentials and slow down price growth by the end of the year and keep inflation at an acceptable level (Ershov, 2016).

Let us calculate a simple empirical model estimating the effect of the Western sanctions upon Russian economy and the counter-sanctions imposed by Russia as an answer to that measure. Our empirical model is based on the trade data obtained from the Comtrade database maintained by the United Nations Statistics Division. Our empirical model can be presented in the following form:

$$
Y_{i j t}=\alpha_{i j t}+\alpha_{t}+\sum \beta_{s} d u m m y_{i j} *(t=s)+\varepsilon_{i j t} \text {, }
$$

where:

$Y_{i j t}-$ is a value of imports coming to the country $i$ of the goods $j$ in any given year $t$;

$\alpha$ - are the regression coefficients; 
dummy - is a sanctions dummy indicating the year of the introduction of sanctions by each party (West and Russia);

$\varepsilon_{i j t}$ - is an error term.

The results are presented in Table 1 that follows. We employ the panel regression model with fixed effects as well as time fixed effects for estimating our results.

Table 1

Empirical calculations of the trade inflows and Western and Russian sanctions (2014-2018)

\begin{tabular}{|c|c|c|}
\hline Model & Western & Russian \\
\hline Sanctions 2014 & -1.757 & $-3.824^{* *}$ \\
& $(1.216)$ & $(1.239)$ \\
\hline Sanctions 2015 & $-3.071^{*}$ & $\left(1.5692^{* * *}\right.$ \\
\hline Sanctions 2016 & $(1.341)$ & $-6.243^{* *}$ \\
& -2.648 & $(1.961)$ \\
\hline Sanctions 2017 & $(1.474)$ & $-6.159^{* *}$ \\
& -0.643 & $(1.890)$ \\
\hline Sanctions 2018 & $(2.125)$ & 21091 \\
\hline $\mathrm{N}$ & & 0.6 \\
\hline Joint significance test (p-value) 2014 & 16379 & 0.01 \\
\hline Joint significance test (p-value) 2015 & 0.51 & 0.01 \\
\hline Joint significance test (p-value) 2016 & 0.27 & 0.01 \\
\hline Joint significance test (p-value) 2017 & 0.17 & 0.01 \\
\hline Joint significance test (p-value) 2018 & 0.11 & 0.09 \\
\hline
\end{tabular}

Note: ${ }^{* *}$ Significant at the 0,001 level (2-tailed). ${ }^{* *}$ Significant at the 0.01 level (2-tailed). ${ }^{*}$ Significant at the 0.05 level (2-tailed); p-values are reported in brackets.

Source: 0wn results.

From the results shown in Table 1, we can see that the Russian counter-sanctions imposed on the Western food imports lead to the decline in trade flows that were much stronger and more efficient than the decline caused by the sanctions imposed by the Western countries on Russia. All in all, even though economic sanctions are sometimes necessary, they do not affect trade security of neither of conflicting parties (Kontsevaya, Smutka, 2020; Krivko et al., 2021). Therefore, it appears that the West should re-think the usefulness of economic sanctions against Russia which might be especially relevant in the post-coronavirus recovery of the world economy (Dreger et al., 2016; Krivko, Smutka, 2020).

\section{Russian Ruble: Can it become the world leading currency?}

In the times of Soviet Union, Russian Ruble was almost exclusively an internal currency unit, with the government's foreign currency exchange rate arbitrarily set. Without a market economy, prices are set by the State Price Committee, and the actual value of the Ruble is difficult to determine. A currency reform in 1947, which equates 10 new Rubles to a new Ruble, tried to replace the inflated money of the war years with a firmer currency (Vernikov, 1995).

Russia has had a comfortable budgeting situation over the last 15 years: rising oil prices and stable economic growth made it possible to balance the deficit, minimize public debt, increase public spending and replenish budget reserves. The increase in expenditure, however, distorted the structure of the budget with accelerated growth in social entitlements (pensions and wages) and selected spending programs (law enforcement and military spending), while spending on human capital and infrastructure increased only very slowly. Oil revenues account for 52 percent of the federal budget. 
As oil prices plummeted in late 2014 economic growth slowed. Treasury's estimated budget revenue would fall 20 percent. At the same time, inflation and the devaluation of the Ruble have forced expenditure to rise in many areas (Khan, 2017).

Therefore, the question is: would Russian Ruble ever become a world's leading currency? The answer is that in the nearest future it is unlikely to compete with dollar, euro, or even yuan. However, in the face of new economic and geopolitical changes such as Brexit or Sino-American trade wars, Ruble might find its place on the international financial arena as the new reserve currency for some investors.

Another interesting feature that has to be debated is whether the Russian Ruble can set on the path of becoming another Digital Currency Electronic Payment (DCEP), a digital currency issued by the central banks. The recent examples are the "digital yuan" (also known as the e-CNY or digital RMB) issued by the People's Bank of China (Louie and Wang, 2021). The concept of digital central bank currency is a well-known concept in the field of economics, where central banks allow citizens to hold their accounts with central banks and provide reliable and secure public savings and payment instruments for the retail and general purpose CBDC. Digital currencies are being studied and tested by many governments and central banks to recognize the many positive effects they can have to contribute to financial inclusion, economic growth, technological innovation and improved transaction efficiency.

For example, the Bank of England provides digital currency by making the bank account accessible to non-bank companies and individuals who need a distributed ledger payment system in the style of Bitcoin. The introduction of digital currency offers the opportunity to rebuild parts of the payment system from scratch and enable greater financial inclusion by allowing people without traditional bank accounts to send and receive money. Public infrastructure in form of a CBDC would for the first time allow the Chinese banking system to compete with digital platforms that would benefit from the first-mover advantage that the network would gain in the financial sector if they were unregulated.

Many banks have questioned the potential of digital money, an electronic version of notes and coins, which has triggered the continued rise of electronic payment systems and the development of alternative currencies such as Bitcoin (Náñez Alonso et al., 2020). An updated real-time payment system is an obvious step for a major advanced economic central bank to issue a CBDC once it understands the monetary and credit implications of digital money. In the United States, which would benefit from replacing most physical cash with a digital central bank currency (CBCD), the Federal Reserve has solved several key policy and implementation issues, including creating a comparative advantage over private issuers and ensuring security and soundness. New technological advances such as distributed ledger technology and mobile computing have allowed individuals to develop payment systems bypassing central banks and central banks to offer a new form of retail payment bypassing intermediaries. The rise of Bitcoin, Ethereum and thousands of other cryptocurrencies that exist in electronic form only has led global central banks to investigate how a national digital currency might work (Zharova, Lloyd, 2018).

In Russia, the potential for the DCEP is represented by the joint venture between the first Russian search engine Yandex and the largest Russian bank Sberbank (Kobylko, 2020). The Yandex financial product called "Yandex.Money" is the leading financial services provider in Russia and neighbouring countries together with Tinkoff and other private banks internet banking services. As a direct way of expansion, Sberbank, the service of the largest Russian state-owned bank, bought $75 \%$ of Yandex. Money, the e-money wallet in Russia used by 17\% of the population, in July 2013 making it the leading player in the Russian online payments market (Kabakova et al., 2016). Established cryptocurrency exchanges are not the easiest options as they require full registration and support the most popular payment methods in the region but there are smaller online exchanges and peer-to-peer (P2P) platforms. P2P trading offers users an open marketplace with flexible access to trade multiple cryptocurrencies with other users, traders and any payment method they prefer. Sberbank is working on a fast B2B payment solution. With the conversion of real money, Russian citizens can make online payments without commissions, for example for mobile services. Thence, the Russian Sberbank does 
not exclude the issue of a virtual currency similar to Bitcoin as the basis of the e-commerce payment system based on Yandex.Money. This would clearly provide a boost for the Russian financial market and make "e-Ruble" one of the pioneers on the world's digital financial market changing the institutional economic landscape for the Russian banking and financial institutions forever.

\section{Conclusions and implications}

Russia is a very important country in the world affairs from a geopolitical point of view. However, viewing from the economic perspectives, the country has many drawbacks and is catching up with the world's leading economies such as China and United States. Given its current economic structure, Russia is highly dependent on the performance of its commodity sectors for many years. Sustainable growth in such a resource-dependent economy requires a stable investment climate characterized by the rule of law and respect for property rights as well as sound macroeconomic policies and, in particular, exemplary budgetary discipline. A good fiscal policy cannot eliminate external weaknesses, but significantly reduce them.

On the one hand, a slowdown in inflation, an improvement in consumer confidence, a stable Ruble, and easing of the central bank's monetary policy had a positive impact on domestic demand in the long run. On the other hand, retail sales growth can collapse as a result of higher unemployment, suggesting that consumer demand remained weak for the next years to come. One should not forget the outcomes of the COVID-19 pandemic and the economic and financial downturn it caused for the world's economy (with Russia not being an exception). It is expected that Russian economy would suffer the results of the pandemic as any other economy in the world. Therefore, it is important to come up with the new solutions that would result in gaining the strong economic position for Russian on the world market. Creating a digital currency and using information and communication technologies and AI-based solutions in economic affairs might become a right way how to achieve this goal. Overall, it appears that more efforts should be directed at supporting the Russian economy, especially at the face of economic sanctions imposed by the West and the post-pandemic recovery measures that are yet to come in the forthcoming years.

In the light of our findings presented above, we think that digital currencies might become a big part of Russia's economic future. The Federal Law on Digital Financial Investments and Digital Currency and amendments to certain legislative acts of the Russian Federation that entered into force on $1^{\text {st }}$ of January 2021 are intended to streamline relations over this issue including cryptocurrency which represent an impeccable sphere of relations but are not regulated. Unlike the digital Ruble, the cryptocurrency does not serve the interests of financial regulators and the tax system, and does not involve a centralized obligation. Transactions do not leave a digital footprint and can be traced to exchanges and other services that convert Bitcoin into a currency issued by the central bank or vice versa. The anonymity of digital currency makes it difficult to trace transactions. Therefore, a digital Russian Rubles (or e-Ruble) might become a better solution that would boost the Russian economy and help to change and modernize the institutional settings of its financial and banking sector.

We think that the digital Ruble might become the means how to improve accessibility and reduce the cost of payment services in Russia. In short, the e-Ruble is conceived as a form of money that can be used for payments and does not compete with bank deposits. This makes it a desirable form of "money" to park savings relative to government-insured and interest-bearing commercial banks deposits. The currency would use a blockchain systems as a way for companies to track goods in their supply chains, track countries of origin, and track payments. Many bankers consider it less risky to transfer assets to other foreign central banks, and issuing a digital currency makes them more attractive. Russia already announced a look at digital currencies and electronic payments as the future of the financial system. The Russian Central Bank's digital currency, to be developed in Russia, should be endorsed by the government and equal in value to its cash and Ruble counterparts. 


\section{Литература / References}

Berezin A., Sergi B.S., Gorodnova N. (2018). Efficiency assessment of public-private partnership (PPP) projects: The case of Russia. Sustainability 10(10): 3713. DOI: 10.3390/su10103713

Bradshaw M., Van de Graaf, Connolly R. (2019). Preparing for the new oil order? Saudi Arabia and Russia. Energy Strategy Reviews 26: 100374. D0I: 10.1016/j.esr.2019.100374

Bulatova E.I., Ipatova E.V. (2021). Financial features of systemically important banks operation in modern conditions. International Journal of Financial Research 12(1): 23-29. D0I: 10.5430/ijfr. v12n1p23

Chebotareva G., Strielkowski W., Streimikiene D. (2020). Risk assessment in renewable energy projects: A case of Russia. Journal of Cleaner Production 269: 122110. D0I: 10.1016/j.jclepro.2020.122110

Chernopyatov A., Makushenko L., Popova V., Antonova N. (2018). Entrepreneurship development and business activity in the Russian Federation. Journal of Entrepreneurship Education 21(4): 1-12. DOI: 10.18411/emiip-03-2019-07

Dreger C., Kholodilin K.A., Ulbricht D., Fidrmuc J. (2016). Between the hammer and the anvil: The impact of economic sanctions and oil prices on Russia's Ruble. Journal of Comparative Economics 44(2): 295-308. D0I: 10.1016/j.jce.2015.12.010

Ershov M.V. (2016). What economic policy does russia need under the sanctions? Problems of Economic Transition 58(3): 181-202. DOI: 10.1080/10611991.2016.1200387

Fifka M.S., Pobizhan M. (2014). An institutional approach to corporate social responsibility in Russia. Journal of Cleaner Production 82: 192-201. D0I: 10.1016/j.jclepro.2014.06.091

Gershman M., Gokhberg L., Kuznetsova T., Roud V. (2018). Bridging S\&T and innovation in Russia: A historical perspective. Technological Forecasting and Social Change 133: 132-140. D0I: 10.1016/j. techfore.2018.03.014

Glazar 0., Strielkowski W. (2010). Turkey and the European Union: Possible Incidence of the EU Accession on Migration Flows. Prague Economic Papers: (3): 218-235. D0I: 10.18267/j.pep.373

Johnson J.E. (1994). The Russian banking system: institutional responses to the market transition. Europe-Asia Studies 46(6): 971-995. DOI: 10.1080/09668139408412212

Kabakova 0., Plaksenkov E., Korovkin V. (2016). Strategizing for financial technology platforms: findings from four Russian case studies. Psychology \& Marketing 33(12): 1106-1111. D0I: 10.1002/mar.20945

Khan M.I. (2017). Falling oil prices: Causes, consequences and policy implications. Journal of Petroleum Science and Engineering 149: 409-427. D0I: 10.1016/j.petrol.2016.10.048

Klinova M.V., Sidorova E.A. (2019). Economic sanctions of the West against Russia: development of the situation. Studies on Russian Economic Development 30(3): 355-364. D0I: 10.1134/ S1075700719030079

Knight A. (2003). The KGB, perestroika, and the collapse of the Soviet Union. Journal of Cold War Studies 5(1): 67-93. D0I: 10.1162/152039703320996722

Kobylko A.A. (2020). Telecommunication ecosystems: Special features of management and interaction. Upravlenets 11(1): 15-23. D0I: 10.29141/2218-5003-2020-11-1-2

Kontsevaya S., Smutka L. (2020). Influence of Russian Sanctions on Agricultural Trade between Russia and the European Union. Acta Universitatis Bohemiae Meridionalis 23(1): 13-26. D0I: 10.2478/acta-2020-0002

Krivko M., Heijman W., Smutka L. (2021). Russia's agricultural import ban: Winners and losers. In: Erokhin V., Tianming G., Andrei J.V. (Eds.) Shifting Patterns of Agricultural Trade. Singapore: Springer. D0I: 10.1007/978-981-16-3260-0_18

Krivko M., Smutka L. (2020). Trade Sanctions and Agriculture Support in Milk and Dairy Industry: Case of Russia. Sustainability 12(24): 10325. D0I: 10.3390/su122410325 
Krivko M., Smutka L., Strielkowski W. (2019). Food security and the trade via lenses of sanctions. Journal of Security and Sustainability Issues 8(4): 815-826. D0I: 10.9770/jssi.2019.8.4(22)

Kudrin A., Gurvich E. (2015). A new growth model for the Russian economy. Russian Journal of Economics 1(1): 30-54. D0I: 10.1016/j.ruje.2015.05.002

Kudrin A., Sokolov I. (2017). Fiscal maneuver and restructuring of the Russian economy. Russian Journal of Economics 3(3): 221-239. D0I: 10.1016/j.ruje.2017.09.001

Liefert W.M., Liefert 0., Seeley R., Lee T. (2019). The effect of Russia's economic crisis and import ban on its agricultural and food sector. Journal of Eurasian Studies 10(2): 119-135. DOI: $10.1177 / 1879366519840185$

Ljovkina A., Brody M., Karagulyan E., Zakharova A., Ljovkin V. (2021). Renewable Energy in Russia: System Analysis of Barriers. BRICS Law Journal 8(2): 89-119. D0I: 10.21684/2412-2343-2021-8-2-89-119

Louie B.L., Wang M. (2021). China's forthcoming digital currency: Implications for foreign companies and financial institutions in China. Journal of Investment Compliance 22(2): 195-200. DOI: 10.1108/J0IC-04-2021-0017

Mau V. (2017). Russia's Economy in an Epoch of Turbulence: Crises and Lessons. New York: Routledge.

McCarthy D., Puffer S. (2002). Corporate Governance in Russia: towards a European, US, or Russian Model? European Management Journal 20(6): 630-640. DOI: 10.1016/S0263-2373(02)00114-7

Morozko N., Didenko V. (2018). Determinants of the savings market in Russia. Banks \& Bank Systems 13(1): 196-208. DOI: 10.21511/bbs.13(1).2018.18

Náñez Alonso S.L., Echarte Fernández M.Á., Sanz Bas D., Kaczmarek J. (2020). Reasons fostering or discouraging the implementation of central bank-backed digital currency: A review. Economies 8(2): 41. DOI: $10.3390 /$ economies8020041

Nie D., Panfilova E., Samusenkov V., Mikhaylov A. (2020). E-learning financing models in russia for sustainable development. Sustainability 12(11): 4412. D0I: $10.3390 /$ su12114412

Rausser G., Strielkowski W., Štreimikienè D. (2018). Smart meters and household electricity consumption: A case study in Ireland. Energy \& Environment 29(1): 131-146. DOI: 10.1177/0958305X17741385

Robinson N. (2013). Economic and political hybridity: Patrimonial capitalism in the post-Soviet sphere. Journal of Eurasian Studies 4(2): 136-145. D0I: 10.1016/j.euras.2013.03.003

Rutland P. (2013). Neoliberalism and the Russian transition. Review of International Political Economy 20(2): 332-362. DOI: 10.1080/09692290.2012.727844

Sachs J. (2019). The Rule of Law and Economic Reform in Russia. New York: Routledge.

Shleifer A., Treisman D. (2005). A normal country: Russia after communism. Journal of Economic Perspectives 19(1): 151-174. D0I: 10.1257/0895330053147949

StrielkowskiW.,Sherstobitova A., Rovny P.,Evteeva,T. (2021). Increasing energy efficiency and modernization of energy systems in Russia: A review. Energies 14(11): 3164. D0I: 10.3390/en14113164

Strielkowski W., Volkova E., Pushkareva L., Streimikiene D. (2019). Innovative policies for energy efficiency and the use of renewables in households. Energies 12(7): 1392. D0I: 10.3390/en12071392

Vernikov A.V. (1995). The Russian Ruble and the currencies of the former republics of the USSR: Problems of mutual convertibility. Russian \& East European Finance and Trade 31(5): 36-46.

Veselovsky M.Y., Izmailov M.A., Bogoviz A.V., Lobova S.V., Alekseev A.N. (2018). Innovative solutions for improving the quality of corporate governance in Russian companies. Calitatea 19(162): 60-66.

Voskoboynikov I.B. (2017). Sources of long run economic growth in Russia before and after the global financial crisis. Russian Journal of Economics 3(4): 348-365. DOI: 10.1016/j.ruje.2017.12.003

Zharova A., Lloyd I. (2018). An examination of the experience of cryptocurrency use in Russia. In search of better practice. Computer Law \& Security Review 34(6): 1300-1313. D0I: 10.1016/j. clsr.2018.09.004 